Отримано: 15.05.2019 p.

Прорецензовано: 21.05.2019 p.

Прийнято до друку: 31.06.2019 p.

email: yuraphinikovskiy@gmail.com

DOI: $10.25264 / 2409-6806-2019-28-110-115$
Фініковський Ю. Мемуари Данила Шумука як історичне джерело. Наукові записки Наиіонального університету «Острозька академія». Серія «ІІторичні науки». Острог, 2019. Вип. 28. С. 110-115.

\title{
Юрій Фініковський
}

\section{МЕМУАРИ ДАНИЛА ШУМУКА ЯК ІСТОРИЧНЕ ДЖЕРЕЛО}

У статті проаналізовано спогади українського дисидента та політв'язня Данила Шумука. Розкрито умови написання та видання мемуарів діяча, можливість їх використання як джерела до історії Украӥни ХХ ст. Окремо акиентовано увагу на особливостях такого виду джерел, необхідності критичного підходу до їх вивчення.

Ключові слова: Данило Шумук, спогади, історичне джерело, мемуари, дисидент, політв'язень.

\section{Yurii Finkovskyi}

\section{MEMOIRS OF DANYLO SHUMUK AS HISTORICAL SOURCE}

There is considered the informational potential of the documents of personal origin, such as memoirs. Memoirs are the important sources in historical events study through the prism of the author's subjective perception, so far as he is able to refute or confirm the official point of view on certain facts, or show the situation from a completely different angle.

The article analyzes the memories of the Ukrainian dissident and political prisoner Danylo Shumuk. In historiography, this issue has not yet been resolved.

Danylo Shumuk is a Ukrainian political prisoner, a member of the Ukrainian national liberation movement, a member of the Ukrainian word association of writers «Word».

He is the author of the books of memoirs «On the Eastern horizon», "Life Sentence», "From Gulag to the free world》 and other.

In the USA and Canada, his memoirs were issued by the Ukrainian diaspora in the 80's and 90's of the 20 th century. The memoirs of Danylo Shumuk caused a great deal of discussion among the Ukrainian public.

Most of the dissident's memoirs have not been published. Today it is stored in archives and individual museums. These memories are very valuable because they are written in the earliest.

They provide information on important events of Ukrainian history of the 20th century. Many of the dissident's memoirs were published in Ukrainian newspapers in France, Canada, USA, Poland, Ukraine.

The paper shown the specifics memoir sources, it defined information opportunities of memoirs.

The terms of writing and publishing the personality memoirs, the possibility of using them as a source for the history of Ukraine of the twentieth century are disclosed.

Separately, attention is paid to the peculiarities of such a source, the need for a critical approach to their study.

Keywords: Danylo Shumuk, memoirs, historical sourse, dissident, political prisoner.

Спогади $€$ найчисельнішим різновидом джерел особового походження. Вони мають важливе значення для вивчення історії, оскільки містять інформацію, що відсутня в інших видах джерел, часто унікальну. Водночас, як справедливо зауважив український дослідник О. Ясь, мемуари вирізняються підвищеною суб'єктивізацією та ідеалізацією інформації, що пов'язано з особою автора, а тому потребують ретельної джерелознавчої критики [25, с. 607-608].

Серед значного масиву вітчизняної мемуарної літератури виділяються спогади українського дисидента та політв'язня Данила Шумука (1914-2002), в яких знайшли відображення основні події української історії XX ст.

У незначній за обсягом історіографії, присвяченій Д. Шумуку, відсутні спеціальні дослідження 3 даного питання. Частково цю проблему піднімали у наукових розвідках Н. Колошук [8], М. Денисюк, В. Трофимович, А. Каляєв [5], Л. Бондарук [2], О. Петренко [10], О. Зінкевич [7], Я. Антонюк [1], Р. Забілий [6] та ін.

3 огляду на це, автор має на меті проаналізувати спогади Д. Шумука як історичне джерело. Досягнення мети передбачає реалізацію наступних завдань: 
- розкрити особливості написання та видання мемуарів діяча;

- з'ясувати основну тематику спогадів;

- визначити можливість їх використання як джерела з історії України XX ст.

Данило Шумук народився 28 грудня 1914 року в с. Боремщина Володимир-Волинського повіту Волинської губернії у багатодітній сім'ї [15, арк. 1]. У 1923-1928 рр. навчався в польській початковій школі с. Підгородно Любомльського повіту Волинського воєводства. Особливе зацікавлення демонстрував до окремих гуманітарних і природничих наук, багато читав [13, с. 86].

В юнацькі роки Д.Шумук захопився комуністичними ідеями, був активним діячем Українського селянсько-робітничого соціалістичного об’єднання («Сельроб»), Комуністичної спілки молоді Західної України (КСМЗУ) на Волині[17, с. 2]. За підпільну діяльність був арештований польською поліцією. У 1934-1939 рр. перебував у в'язницях м. Ковель, Ломжа, Білосток [12, с. 8].

Повернувшись додому, активно включився в процес становлення радянської влади: організував сільські комітети та загони міліції, брав участь у підготовці до місцевих виборів, працював секретарем сільради $[11$, с. 8$]$. Згодом перейшов на педагогічну роботу, викладав географію в середній школі с. Підгородно Любомльського району, вступив на заочне відділення Луцького педінституту. Після деяких розбіжностей з дирекцією навчального закладу працював на посаді кредитного інспектора в Держбанку м. Любомль[15, арк.1].

У травні 1941 року Д.Шумук був призваний у лави радянської армії [22, с. 64]. Із початку німецько-радянської війни перебував у складі 38 окремого саперного батальйону 5-ї армії [3, с. 78-79]. У вересні 1941 року потрапив у німецький полон, покарання відбував у таборі для військовополонених у м. Хорол Полтавської обл. [9, с. 841]. Згодом організував втечу й повернувся на Волинь. 3 огляду на переслідування зі сторони німецької поліції, змушений був залишити дім. Працював на різних посадах у сільських господарствах Рівненщини [15, арк. 2].

Із березня 1943 до лютого 1945 років перебував у лавах УПА, де викладав економіку та географію на вишкільних курсах. Діяв у межах Волинської, Рівненської, Житомирської та Київської областей $[12$, c. 8$]$.

У лютому 1945 року Д.Шумук був заарештований радянськими органами держбезпеки. Військовим трибуналом військ НКВС Рівненської області був засуджений до смертної кари, заміненої згодом на двадцять років табірного ув'язнення $[11$, с. 8]. До березня 1956 року перебував на засланні у містах Норильськ і Володимир. Зокрема, у Норильську протягом червня-вересня 1953 року був організатором повстання політв'язнів у третьому каторжанському таборі [2, с. 40-41].

Після звільнення повернувся на Волинь, згодом із сім'єю переселився в Дніпропетровську область. Через відмову співпрацювати з органами КДБ у листопаді 1957 року був заарештований $[1$, c. 516]. У травні 1959 року засуджений Волинським обласним судом за «антирадянську пропаганду та агітацію» на десять років ув'язнення. Покарання відбував у таборах на Воркуті, Тайшеті, Мордовії [16, арк. 2-3].

Данила Шумука було звільнено в листопаді 1967 року [16, арк. 3]. Деякий час проживав у м. Київ, згодом - у м. Богуслав Київської області. В цей період він познайомився і зблизився з дисидентами Іваном Світличним, Свгеном Сверстюком, Аллою Горською, Надією Світличною, Василем Стусом, Михайлом Горинем та ін. [23, с. 103]. В 1968-1972 рр. працював над написанням автобіографічного нарису «Оповідання про пережите і передумане» [1, с. 517].

За написання спогадів 12 січня 1972 року був заарештований органами радянської держбезпеки та засуджений на десять років ув'язнення та п'ять років заслання. Покарання відбував у таборах Мордовії [24, с. 942]. У 1972-1974 роках тричі звертався з проханням до керівництва СРСР про позбавлення його радянського громадянства[16, арк. 3-4]. У 1974 році у Парижі були підготовлені до друку спогади Д. Шумука, видані згодом в м. Балтимор (США) окремою книгою під назвою «За східним обрієм» [20].

У лютому 1979 року політв'язень увійшов до складу Української Гельсінської Групи. В 19821987 pр. перебував на засланні в с. Каратобе Уральської області (Казахстан) [1, с.518].

У 1983 році у м. Детройт (США) вийшла доповнена книга спогадів Д. Шумука «Пережите і передумане» [21], згодом аналогічне видання побачило світ англійською мовою.

У 1987 році Д. Шумук був звільнений і на запрошення родичів емігрував у Канаду [23, с. 168]. 3 цього часу він брав участь у зустрічах із українською діаспорою та громадськістю у містах Канади, США, Аргентини, Франції, де розповідав про свій життєвий шлях [7]. 
У 1991 році в м. Торонто (Канада) вийшла книга спогадів Д.Шумука «Із Гулагу у вільний світ», до того ж він активно друкувався в українських діаспорних газетах і часописах [23]. 3 моменту проголошення Незалежності України неодноразово приїжджав на Батьківщину. У 1998 році тут було видано останню книгу його спогадів під назвою «Пережите і передумане»[22].

У листопаді 2002 року Д. Шумук повернувся на постійне проживання у м. Красноармійськ Донецької області. Помер у травні 2004 року. Посмертно був нагороджений орденом «За мужність» І ступеня [1, с. 518].

Роботу над написанням мемуарів Данило Шумук розпочав ще під час перебування в другому радянському ув'язненні $[15$, арк. 2]. На одному із пізніших допитів він зізнався, що в період ув'язнення в Дубравному виправному таборі (Мордовська АРСР), протягом 1964-1966 рр., ним складено два зошити власних спогадів, які згодом були вилучені адміністрацією [4, арк. 244].

Уже перебуваючи на волі, з осені 1968 і до початку 1971 років, Данило Шумук працював над написанням автобіографічного нарису «Оповідання про пережите» [ 4, арк. 245 ]. Цей твір пізніше у кількох примірниках був переданий для ознайомлення Івану Світличному, Надії Світличній, Свгену Сверстюку, Зіновію Антонюку та ін. [4, арк. 246].

У заяві до ЦК КПУ від 29 лютого 1972 року арештований Данило Шумук пояснював: «Не писати тої книги я не міг. Почуття обов'язку перед грядущими поколіннями заставило мене взятися за перо і написати про все це так, як я бачив, відчував, пережив і сприймав кожним своїм мускулом, кожним нервом і взвилиною мозку. Пишучи свої мемуари, я старався лише точніше й як найяскравіше розкрити всі події і свою участь. Відношення до них до війни, в війну і після війни, а також показати еволюцію переконань і мислення, яка проходила у мене на основі особистих переживань, спостережень і роздумів над ними...» $[1$, с. 517$]$.

У ході операції «Блок» співробітниками КДБ у січні 1972 року окремі тексти у згаданих вище діячів, і в самого автора, були вилучені [4, арк. 5-6]. Однак, один із примірників, переписаних рукою Надії Світличної, вдалося перефотографувати та вивезти за кордон зв'язковому видавництва «Смолоскип», студентові журналістики з м. Торонто Богдану Колосу[7].

Дещо пізніше, спогади Данила Шумука були надруковані у видавництві газети «Українське слово» в Парижі, головним редактором якої був голова ОУН (м) Олег Штуль-Жданович [7]. Вихід у світ видання «За східним обрієм» (1974 р.) спричинив величезну кампанію проти їі автора в українській діаспорі, а також і в Радянському Союзі [8].

Незважаючи на гостру полемічну дискусію, у 1983 році спогади Д.Шумука 3 доповненнями було перевидано у м. Детройт (США) під назвою «Пережите і передумане» [21].

Після звільнення у 1987 році Данило Шумук переїхав на постійне місце проживання в Канаду. 3 того часу він почав активно друкуватися в українських діаспорних виданнях, далі працював над доповненням спогадів. В 1991 році у м. Торонто вийшла друком його наступна книга «Із Гулагу у вільний світ»[23].

Останнє видання мемуарів діяча вийшло у Києві у 1998 році під назвою «Пережите і передумане. Спогади й роздуми українського дисидента-політв'язня з років блукань і боротьби під трьома окупаціями України(1921-1981)». У передмові до книги Д.Шумук писав: «Розповідаючи про себе в похилому віці, мабуть, неможливо передати почуттів, світосприймання з років свого дитинства та юности без печаті багатолітнього життєвого досвіду. Важко, і то дуже важко, розповідати про себе об'єктивно. Одначе в похилому віці значно легше засуджувати дії своєї юности, ніж у юнацькі часи. Отже, я хочу оглянути своє минуле з вершин багатолітнього досвіду і дати йому, по можливості, об'єктивну оцінку» [22, с. 11].

Загалом, маємо зауважити, що між рукописними та опублікованими спогадами автора $є$ ряд відмінностей. Очевидно, що більш цінними для дослідників будуть мемуари, написані Д. Шумуком найраніше [3]. Саме вони точніше передають характер і зміст подій, які спостерігав діяч. Натомість, більш критично варто підійти до текстів, написаних пізніше, адже на характер оповіді завжди негативно впливає притуплення гостроти пам'яті автора, а також зміни, що відбулися у його поглядах та сприйнятті дійсності. Водночас, не варто опускати і той факт, що пізніші мемуари Д. Шумука, видані окремими книгами, піддавалися літературній критиці та обробці. В порівнянні з неопублікованими спогадами в них відсутні окремі події та факти.

Загалом оповідь про свій життєвий шлях Д.Шумук розпочинає із дитячих років [22, с. 11-12]. Особливу увагу він звертає на родинні відносини, побут, навчання в польській школі. Описуючи 
свої дитячі та юнацькі роки, автор акцентує увагу на діяльності ліворадикальних партій та організацій( КПЗУ, КСМЗУ, «Сельроб» та ін.) на теренах Волині у міжвоєнний період, свою участь у них $[17$, c. 2]. Окремо згадується і функціонування польських владних структур, правоохоронних органів на теренах краю в 20-30-ті pp. XX ст. [22, с.17-18].

Значна частина спогадів присвячена перебуванню Д.Шумука у польських тюрмах у містах Ковель, Ломжа, Білосток [12, с. 8]. Тут він детально описує умови ув'язнення, характер відносин із іншими затриманими тощо[11, с. 8]. Загалом ця частина мемуарів може бути використана науковцями для дослідження польської пенітенціарної системи міжвоєнного періоду.

Окремо автор згадує про становлення радянської влади на Волині в 1939-1941 pp. [21, с. 100-102]. Будучи безпосереднім учасником подій, Д.Шумук вдається до деталей при описі проведення виборів до місцевих органів влади, роботи навчальних закладів, відносин між місцевим населенням і прибулим партійним активом та ін. [18, с. 4].

Велика увага автора приділена німецько-радянській війні в період червня-серпня 1941 року. Як свідок, він виразно змальовує реалії фронту, повсякденне життя рядових солдатів, відступи окремих частин армії, полон у нацистському таборі для військових у м. Хорол на Полтавщині тощо [19].

Одну з найбільших частин мемуарів Д. Шумука присвячено його перебуванню в українському національно-визвольному русі в період Другої світової війни [20]. Так, він детально описує свої перші контакти із членами ОУН, діяльність на посаді політичного інструктора УПА, побут повстанців, внутрішні розбіжності між керівництвом окремих відділів підпілля, діяльність спецорганів ОУН, відносини з іншими партизанськими рухами [10]. Автор торкається також теми тогочасного українсько-польського конфлікту $[5,8]$, звертає увагу на діяльність радянських органів безпеки в боротьбі 3 націоналістичним рухом на теренах Волинської, Рівненської, Житомирської, Київської областей.

Об'ємну частину у спогадах Д.Шумука займає розповідь про його арешти радянськими органами державної безпеки, перебування в умовах ув'язнення у виправних трудових таборах. Тут, зокрема, варто звернути увагу на опис Норильського повстання політв'язнів, співкерівником якого він був. Поруч з іншими відомими мемуарами $з$ цієї тематики, тут добре прослідковано причини, передумови, хід та підсумки самої акції [2, 38-40].

Цікавими, на наш погляд, для дослідників будуть спомини діяча і в частині, де згадано про відносини між українськими політв'язнями, їх стосунки, протидії радянській репресивній системі [23, c. 94-95].

Інформативними $є$ також спогади Д.Шумука про його перебування у середовищі українських дисидентів, знайомство із Василем Стусом, Аллою Горською, Свгеном Сверстюком, Іваном Світличним, Надією Світличною, В'ячеславом Чорноволом, Іваном Дзюбою та багатьма іншими. Окрему увагу автор приділяє співпраці з окремими із них, зокрема, в плані видання власного автобіографічного нарису[23, с. 217-218].

Значну частину мемуарів діяча присвячено його останньому радянському ув'язненню та засланню (1972-1987 рр.). Вони є оригінальними з тої точки зору, що дають змогу прослідкувати взаємовідносини українських дисидентів в умовах ув'язнення (зокрема, т. зв. «сосновський конфлікт політв'язнів»), з'ясувати роль міжнародних правозахисних організацій у справах звільнення арештованих тощо[22, с.383-384].

Також доволі інформативними є мемуари Д.Шумука щодо організації та життя української діаспори в США, Канаді, Франції [23].

Поряд із цим у спогадах автора знаходимо й інформацію на іншу тематику. Зокрема, показовими є згадки про власні розмови із свідками Голодомору 1932-1933 pp.[17, с. 2], сталінських репресій 30-х рр. ХХ ст. [12, с.8] та ін.

Таким чином, мемуари Данила Шумука можуть бути використані як джерело до окремих тем 3 новітньої історії України. При опрацюванні спогадів варто звертати увагу на їх суб'єктивний характер. Тому, насамперед, вони вимагають критичного підходу, зокрема, їх зіставлення із іншими джерелами, де відображені ті самі події.

\section{Список використаних джерел та літератури:}

1. Антонюк Я. Дисидентський шлях Данила Шумука. Минуле і сучасне Волині та Полісся. Любомль $і$ Любомльщина в украӥнській та європейській історії. Луцьк, 2017. С. 516-519.

2. Бондарук Л. Роль українського Руху опору в організації Норильського повстання. Історичний архів. Наукові студіï. Миколаїв, 2010. Вип. 4. С. 38-43. 
3. Відділ рукописних фондів та текстології Інституту літератури імені Т.Г.Шевченка НАН України. Ф.202. Архів Д.Л.Шумука. Спогади. 89 с.

4. ГДА СБУ (Галузевий державний архів Служби безпеки України). Ф. 6. Спр.70827. Д.Шумук (уся справа в 10 томах). Т I. 440 арк.

5. Денисюк М., Трофимович В., Каляєв А. Українсько-польський конфлікт у роки Другої світової війни у спогадах. Наукові записки. Серія «Історичні науки». Острог, 2008. С. 247-263.

6. Забілий Р. Як КДБ «дописував» спогади повстанців. URL: http:/www.istpravda.com.ua/ columns/4d7ec7176e $86 \mathrm{e} /$

7. Зінкевич О. Про спогади Д.Шумука і «всезнаюче» КДБ. URL: http://www.istpravda.com.ua/ columns/4d828b3590742/

8. Колошук Н. Конфлікт між українцями і поляками у книзі Д.Шумука «Пережите і передумане». $У$ noшуках правди.: Збірн. міжн. наук. конфер. :«Украӥнсько-польський конфлікт на Волині в роки Другої світової війни: генезис, характер, перебіг і наслідки. Луцьк, 2003. С. 474-482.

9. Овсієнко В., Рапп І. Данило Лаврентійович Шумук. Міжнародний біографічний словник дисидентів краӥн Центральної та Східної Свропи й колишнього СРСР. Т.1. Україна. Частина 2. Харків, 2006. С.841-844.

10. Петренко О. Деконструкції декоративного. Про провокаційні спомини Данила Шумука та його жіночі портрети. URL: http://uamoderna.com/blog/214-214

11. Стех Я. Майже половина життя в ув’язненні. Наше Слово. 2004. 30 листопада. №48. С. 8.

12. Тима П. «Я був той комуніст, що сидів у тюрмі, а не той, що саджав до неї інших». Наше Слово. 2004. 7 листопада. № 28. С.8.

13. Фініковський Ю. Данило Шумук у комуністичному русі на Волині ( 20-30-ті рр. ХХ ст.). Наукові записки Національного університету «Острозька академія». Серія «Історичні науки». Острог, 2018. Вип. 27. C.85-89.

14. Шанковський Л. Спомини Д. Шумука у світлі фактів. Визвольний илях. 1975. Ч.1-4.

15. Шумук Д. Автобіографія:[Машинопис]. Фонди Любомльського краєзнавчого музею. Інв. №НДФ-3317. 2 арк.

16. Шумук Д. Звернення до членів Гельсінської комісії: [Машинопис]. Фонди Любомльського краєзнавчого музею. Інв. №КДФ-5285. 4 арк.

17. Шумук Д. Комуністичне словоблудство. Украӥнське слово. Париж. 1991. 12 травня. С.2.

18. Шумук Д. Моя рідна умираюча Боремщина. Українські Bicmi. Детройт, 1994. 25 грудня. С.4.

19. Шумук Д. Від Майорщини до Хоролу. Сучасність, 1980. Ч. 7-8. С. 224-232.

20. Шумук Д. За східним обрієм: Спомини. Париж, Балтимор, 1974. 447 с.

21. Шумук Д. Пережите й передумане: Спогади й роздуми українського дисидента-політв'язня з років блукань і боротьби під трьома окупаціями України (1921-1981). Детройт, 1983. 536 с.

22. Шумук Д. Пережите й передумане: Спогади й роздуми українського дисидента-політв'язня з років блукань і боротьби під трьома окупаціями України (1921-1981). Київ, 1998. 431 с.

23. Шумук Д. Із Гулагу у вільний світ. Торонто, 1991. 259 с.

24. Шумук Данило. Українська Гельсінська група.1978-1982: документи і матеріали. Торонто, Балтимор. 1983. С.942-958.

25. Ясь О.В. Мемуари. Еничиклопедія історії України. Київ, 2009. Т.6. С.604-608.

\section{References}

1. Antoniuk Ya. Dysydentskyi shliakh Danyla Shumuka. Mynule i suchasne Volyni ta Polissia. Liuboml i Liubomlshchyna v ukrainskii ta yevropeiskii istorii. Lutsk, 2017. S.516-519.

2. Bondaruk L. Rol ukrainskoho Rukhu oporu v orhanizatsii Norylskoho povstannia. Istorychnyi arkhiv. Naukovi studii. Mykolaiv, 2010. Vyp. 4. S.38-43.

3. Viddil rukopysnykh fondiv ta tekstolohii Instytutu literatury imeni T.H.Shevchenka NAN Ukrainy. F.202. Arkhiv D.L.Shumuka. Spohady. 89 s.

4. HDA SBU (Haluzevyi derzhavnyi arkhiv Sluzhby bezpeky Ukrainy). F. 6. Spr.70827. D.Shumuk (usia sprava v 10 tomakh). T. I. 440 ark.

5. Denysiuk M. Trofymovych V. Kaliaiev A. Ukrainsko-polskyi konflikt roky Druhoi svitovoi viiny u spohadakh. Naukovi zapysky. Seriia «Istorychni nauky». Ostroh, 2008. S. 247-263.

6. Zabilyi R. Yak KDB «dopysuvav» spohady povstantsiv. URL: http://www.istpravda.com.ua/ columns/4d7ec7176e86e/

7. Zinkevych O. Pro spohady D.Shumuka i «vseznaiuche» KDB. URL: http://www.istpravda.com.ua/ columns/4d828b3590742/

8. Koloshuk N. Konflikt mizh ukraintsiamy i poliakamy u knyzi D.Shumuka «Perezhyte i peredumane». U poshukakh pravdy.: Zbirn. mizhn. nauk. konfer. :«Ukrainsko-polskyi konflikt na Volyni v roky Druhoi svitovoi viiny:henezys, kharakter, perebih i naslidky. Lutsk, 2003. S. 474-482.

9. Ovsiienko V. Rapp I. Danylo Lavrentiiovych Shumuk. Mizhnarodnyi biohrafichnyi slovnyk dysydentiv krain Tsentralnoi ta Skhidnoi Yevropy y kolyshnoho SRSR. T.1. Ukraina. Chastyna 2. Kharkiv, 2006. S.841-844.

10. Petrenko O. Dekonstruktsii dekoratyvnoho. Pro provokatsiini spomyny Danyla Shumuka ta yoho zhinochi portrety. URL: http://uamoderna.com/blog/214-214

11. Stekh Ya. Maizhe polovyna zhyttia v uviaznenni. Nashe Slovo, 2004. 30 lystopada. №48. S. 8.

12. Tyma P. «Ia buv toi komunist, shcho sydiv u tiurmi, a ne toi, shcho sadzhav do nei inshykh». Nashe Slovo, 2004. 7 lystopada. № 28. S.8. 
13. Finikovskyi Yu. Danylo Shumuk u komunistychnomu rusi na Volyni (20-30-ti rr. XX st.). Naukovi zapysky Natsionalnoho universytetu «Ostrozka akademiia». Seriia «Istorychni nauky». Ostroh, 2018. Vyp. 27. S.85-89.

14. Shankovskyi L. Spomyny D. Shumuka u svitli faktiv. Vyzvolnyi shliakh. 1975. ch.1-4.

15. Shumuk D. Avtobiohrafiia:[Mashynopys]. Fondy Liubomlskoho kraieznavchoho muzeiu. Inv. № NDF-3317. 2 ark.

16. Shumuk D. Zvernennia do chleniv Helsinskoi komisii: [Mashynopys]. Fondy Liubomlskoho kraieznavchoho muzeiu. Inv.№KDF-5285. 4 ark.

17. Shumuk D. Komunistychne slovobludstvo. Ukrainske slovo. Paryzh, 1991. 12 travnia. S.2.

18. Shumuk D. Moia ridna umyraiucha Boremshchyna. Ukrainski Visti. Detroit. 1994. 25 hrudnia. S.4.

19. Shumuk D. Vid Maiorshchyny do Khorolu. Suchasnist, 1980. Ch. 7-8. S. 224-232.

20. Shumuk D. Za skhidnym obriiem: Spomyny. Paryzh. Baltymor, 1974. 447 s.

21. Shumuk D. Perezhyte y peredumane: Spohady y rozdumy ukrainskoho dysydenta-politviaznia z rokiv blukan i borotby pid troma okupatsiiamy Ukrainy (1921-1981). Detroit, 1983. $536 \mathrm{~s}$.

22. Shumuk D. Perezhyte y peredumane: Spohady y rozdumy ukrainskoho dysydenta-politviaznia z rokiv blukan i borotby pid troma okupatsiiamy Ukrainy (1921-1981). Kyiv, 1998. $431 \mathrm{~s}$. 